\title{
MAFB Gene
}

National Cancer Institute

\section{Source}

National Cancer Institute. MAFB Gene. NCI Thesaurus. Code C97671.

This gene plays a role in both hematopoiesis and transcriptional modulation. 